\title{
On the Experience Marketing Strategies of Maky Food Company
}

\author{
Song Han \\ School of Administration, Changchun University \\ 6543 Wei Xing Road, Changchun 130022, China \\ Tel: 86-431-8558-2731Ｅ-mail: han11-1978@163.com
}

Xiaoli Sun

Department of Basic Teaching, College of Optical and Electronical Information

Changchun University of Science and Technology

399 Da Xin Road, Changchun 130012, China

Tel: 86-431-8601-5052 E-mail: xiaoli33770@163.com

Received: November 23, 2011

Accepted: December 19, 2011 Published: February 1, 2012

doi:10.5539/ass.v8n2p283

URL: http://dx.doi.org/10.5539/ass.v8n2p283

\begin{abstract}
This paper focuses on experimental marketing strategies in Maky Food Company. From five aspects, this paper talks this company did a great efforts to touch her aim. Due to this kind of marketing strategies, who concerns customer's senses, emotion, thinking and action, her products will be provided a new way for the future development. Besides, I hope it will do inspire the other colleague enterprises.
\end{abstract}

Keywords: Experience, Experimental marketing, Experimental economy

Maky Food Company was born in 1994 in the ancient capital, Xian. From the establishment, she always upholds the management idea — customer is god, and continuously contributes to the products innovation and market confidence. At the beginning, she was a group with tens staff and a small food factory providing single product only. With their effort, she has changed a lot. Now the company has developed into a modern major food enterprise, nearly owing three thousand staff and providing variety products to her customers. The major products include six complete product line: moon cakes, cake, bread, the west point, midpoint, cold drinks. About her geographical area, she takes the Heilongjiang and Shanxi as the core market, and her branches in Xian, Harbin, Changchun, Daqing, Beijing, Tianjin and Shenyang. In the producing process, the company uses the constant temperature dustproof and modern workshops; furthermore, she introduces advanced producing equipments. And for her packaging area, she is the pioneer for the use of grade purification system. Producing conditions have reached the international standard, meanwhile having been admitted by IS09001 quality management system and HACCP food safety management system. Because of the pursing spirit, Maky Food Company has got many awards in nearly 20 years during her development process. Now, Maky Food Company is a famous brand among national ranks.

However, as a famous food company, former achievements are courage instead of end. Facing the challenge coming from others, especially "HaoLiLand" "Di leah", she still has a long way to go. On marketing strategy, Maky Food Company has not reaped a lot from the traditional applications, but new measures are needed.

\section{Theoretical basis}

The United States "Harvard Business Review" once made an essay on the Experience Economy Era", which points out that: The traditional economy has been the main concern of powerful products, beautiful appearance and advantage in price, while experience economy pays more attention to life and perspective situation, it shapes sensory experiences and thinks identity to draw consumers' attention. Then it will change consumer's behavior and find a new space for products and their values. Viewing on the current consumption behavior, the consumers not only buy useful things, but show themselves.

In other words, in today's society, purchasing is not the aim for people to satisfy their material needs, but the real 
meaning reflecting by products. Therefore, the economic development of the evolution process has changed, from traditional economy to the present experience economy. It bases on the enterprise service, goods material, creating memorable experience for customers. So, the experimental economy is the new situation in business field, followed by experimental marketing, especially in domestic food industries, this kind marketing is located in the frontier.

Additionally, this strategy requires enterprise to stand in the consumer sensory, emotion, thought, action and five aspects to design marketing activities. The following examples are from Maky Food Company's product bread, which searches for specific about the company future experimental marketing way.

\section{Specific operation}

\subsection{Senses}

Operating on people 's sight, hearing, touch, taste and smell to create the feeling of consciousness experience, senses marketing can distinct recognition of products, stimulating customer purchasing motivation and increasing the added value of products, etc. As the first hurdle, the layer of marketing position is self-evident. Maky Food Company can have further differentiation for her products, and then operating retail stores, providing brewing space for each product line fully. Meanwhile, no matter where Maky Food Company is located, she pays attention on her face, such as connecting glass, concising store decoration and building materials elements. Because of its special design, art fashion is perfectly interpreted out. Consumers have the immediate feeling being placed in a complete bread world, and do their selection, without worrying about lackness or bread species.

Then, consumers will see bakery which mainly uses white marble, stainless steel and glass, this three kinds of elements for its design. At the same time, through the perspective of glass, consumers can watch the cooking process completely with a great visual impact. After watching, you will strongly believe the initial first feeling, and don't regret to visit here. But the key is taste, which is the only goal for customers to visit Maky Food Company.

Comparing with the Beijing duck being cooked with special thick sweet shredded and ancient capital culture breath, watching its processing after taking a great appetite, customers have a bite, enjoying music, smelling fresh bread fragrance from the oven, tasting such various bread, finally choosing his beloved products-this is pleasing affair. Five feelings should be the power for consumer's visit.

\subsection{Emotion}

Just as its name implies, the goal of emotional marketing is to create emotional appeal experience. Feelings and emotions can be positive mood, can also be joy, pride and even strong. Maky Food Company is trying her best to form psychological interaction with her consumers. Obviously, in this marketing process, Maky Food Company needs to understand what is the stimulation to her consumers' purchasing purpose, and naturally they are infected and integrated into this commercial circle. With great efforts, Maky Food Company did a lot. For example, for each of the bread, they take a novel and chic good name, which brings some dialect characteristics; this was acted at the new beginning in northeast in China.

Additionally, by contacted with all kinds of today's event at home or abroad, their bread can be named "Shenzhou eight", "Olympic", "2012" and so on. And in concreting production process, they must give highlight regarding the names of the respective characteristics, Shenzhou eight bread should be made of shuttle shape, with cream and accessories lines out "Shenzhou eight," the words. Seeing it, customers have feelings again about our nation's power, and they are proud of air power. And "the Olympic" is a double form, the Great Wall and Big Ben patterns attached to each piece of bread, which reflects the present and the next host. This kind of design is to help all of the customers to the memory of the last game and the wish of next game. About 2012, they want to strengthen the sense of era.

In order to attract the youngster's attention, they can make their products optionally weak, yet outstanding. We hope that because of this special design, these names and makings it will give consumers an informer new feeling. Maky Food Company will benefit from emotional marketing smoothly.

\subsection{Thinking}

The core of the thinking marketing is intelligence. It means that thinking marketing is to attract consumer's creative curiosity, interest and research on the problems. In other words, thinking marketing is to provide opportunity for consumers to experience their cognition and solution to problem. In high-tech products industry, thinking activity has been generally used, but for food processing industry, especially pastry, is not used more. 
In this field, Maky Food Company is precedent. Because it is very creative, to any bread, they design a beautiful and moving brand story, and put these stories written in the tag, then put in the bread of the corresponding counter next to the product. Therefore, entering into the store, Consumers can not only choose and buy, but enjoy the bread with their "color, aroma, taste and shape", and "read" the bread fully. I $t$ is one kind of active talk between customers and bread.

For instance, there is bread named "baby". Reading her name, you can find out a story like this: One sunny morning, with a loud cry, a lively and lovely baby came to this world. In order to celebrate the happiness hour, the grandma went to kitchen to make some bread for the entire family. But accidentally, the grandma made a mistake; she used special chili sauce as a jam daub on the immature bread roast. Unexpectedly, the baked bread was absolutely delicious. Later, this kind of bread was used as their hospitality. "Baby" came out followed as a memorial. For "honeymoon", it is basis on love story. Soft litchi matching with sweet red bean constitutes a story of a hero and heroine emotional foundation, which tells a across love story between a Japanese baker and a French girl, working in China. It is a good international love. During the producing, the baker used moon shape external which meant that a sweet results of their love. It is so old and creative that will naturally cause consumer deep thinking, and consequently it will become a bridge between consumers and themselves.

\subsection{Action}

Action marketing means that it will make a different life by action experience and interaction. As a consumer, the life change can come from their own, is also likely to be stimulated by results, and the latter is related to enterprise. Every one of us, no matter withdrawn or not, has some hobbies more or less, so every field of the elites may be our respective idols.

As a result, their words, behaviors, even if eyes will enlighten consumers, even setting off a furor. And with the differences of these idols behavior, the result will be quite different. In fact, about their moon cakes products, Maky Food Company had done some experiences in the past, they cooperated with some image of film and television or health sports stars to do advertise, and they achieved good marks. And now, bread products can use this way to sell.

In addition, sponsorship event way can also be regarded as a kind of ideal way, and later there is a good chance for Maky Food Company--- Harbin Ice and Snow Festival. In turn, white's the night. All the tourists suddenly stop in front of logo, which says that Harbin Maky Food Co., LTD warmly celebrates the fifth Harbin ice festival opening and Harbin Maky Food Co., LTD wishes the 5th Harbin ice festival a complete success. Immersing in icy world, the inside tourists can catch different bread posters. This warm winter nights comes from Maky Food Company and its bread products, and then visitors move to choose bread.

\subsection{Relevance}

From some sense, related marketing is senses, emotion, thinking and action marketing, which is superior to the private feelings, character. It pays more attention to self change and hopes that others show interest in it. Then, she will establish an individual certain brand preferences. Totally, there are at least 200 kinds bread products in Maky Food Company, she will face high selling needs or low one.

In order to solve this kind of difficulties, she can model on fashion behavior.

In addition to ensure a few signs of significant relative products position, she tries to change sales management system by changing the products' feedback. This new selling concept needs corresponding product line to ensure the products number. Therefore, the company must improve innovation and shorten product market of operational cycle. On the surface, this marketing strategy is not special, but binding commodity characteristic. Then Maky Food Company sales not only bread, but fashionable consumption concept.

\section{Conclusion}

Not only the Harvard Business Review, but future scientists Alwin TuoFuLe, who has successfully predicted the "third wave", attended central television station "Dialogue" show on the scene on 2 December 2001. He predicted that the next step to the service economy is experience economy. People will create more and more experiences about economic activities, and the businessman will also provide experience service to win. In the past ten years, as the words coming from Alwin TuoFuLe, every profession has gone gradually towards the economic experience, as food processing cannot fall on anyone. In fact, Maky Food Company must try to grasp the marketing strategy of $5 \mathrm{D}$ applications, then the whole enterprise. Doing in this way, ordinary bread cakes business process will become unique experimental trip, consequently to new success. 


\section{References}

Byrd Schmidt. (1999). Experience Marketing: How to Enhance the Affinity of Company and Brand. Beijing: Tsinghua University Press.

Chen, Guangxi. (2011). Experience Marketing and Brand Building in Longhu Real Estate. Beijing: Science press, March.

Gao, Guang. (2011). Retailers Marketing Strategy Based on the Customer Emotional Experience. Beijing: Science press, August.

Han, Yaoyang. (2011). On the New Economic Era Marketing Innovation. Beijing: Higher Education Press, September.

Hu, Chengyu. (2011). Brand Clothing Terminal Experience Marketing. Beijing: Tsinghua University Press, April.

Zhao, Rui. (2010). Reading on Car Experience Marketing. Dalian: Northeast Financial University Press, November. 